\title{
DEVELOPMENT OF STRENGTHENED BIOACTIVE CALCIUM PHOSPHATE-SILICATE GLASS CERAMICS FOR BONE IMPLANTS
}

\author{
Oksana Savvova1, ${ }^{\circledR}$, Vasyl Shymon ${ }^{2}$, Oleksii Fesenko $^{1}$, Olena Babich $^{3}$, \\ Serhii Alfeldii ${ }^{4}$
}

https://doi.org/10.23939/chcht14.01.109

\begin{abstract}
Cumulative experience in the field of development of bioactive glass ceramics for bone implants and methods of strengthening thereof have been analyzed. Compositions were selected and model glasses were synthesized, the relationship between viscosity and crystallization ability of glass ceramics has been studied. Composite materials based on the glass ceramics and zirconia have been synthesized, their mechanical properties studied, and feasibility of their use in the creation of bone implants has been established.
\end{abstract}

Keywords: calcium phosphate-silicate glass ceramics, crystallization ability, viscosity, mechanical properties, strengthening, bone implants.

\section{Introduction}

Millions of people worldwide experience degenerative and inflammatory problems of bones and joints. These problems constitute a de facto majority of chronic diseases in people over 50 years of age in developed countries. Apart from that, it is expected that the percentage of people over 50 experiencing bone diseases will be doubled before 2020 [1]. One of the causes of incapacitation are diseases and post-traumatic conditions associated with the need of reconstruction and substitution of bone tissue, prosthetics of locomotor system fragments, in particular longitudinal bones [2]. The importance of creating new polyfunctional materials for medical applications is a result of the shortening of social and working age of a person, which is a pressing world problem. Today, numerous studies are conducted to

\footnotetext{
${ }^{1}$ O.M. Beketov National University of Urban Economy in Kharkiv, 17, Marshala Bozhanova St., 61002 Kharkiv, Ukraine

2 State Higher Eductional Institution "Uzhhorod National University"

22, Kapushinska St., 88000 Uzhhorod, Ukraine

${ }^{3}$ Scientific Research Institution "Ukrainian Scientific Research Institute of Ecological Problems"

6, Bakulina St., 61002 Kharkiv, Ukraine

${ }^{4}$ Tyachiv District Hospital, Traumatology Department

48, Zhovtneva St., 90500 Tyachiv, Ukraine

savvova_oksana@ukr.net

(C) Savvova O., Shymon V., Fesenko O., Babich O., Alfeldii S., 2020
}

solve this problem, which are aimed on creating biocomposites capable of inducing osteogenesis. Optimal choice of a material or a combination of materials for implantation and their rational placement allow to achieve positive clinical results [3]. Using highly efficient materials in prosthetics is an important factor of retaining functionality of a body as a whole.

Prosthetics based on metallic constructs (titanium, titanium nickelide) are widely used nowadays in bone implanting. However, their application is complicated by a galvanic phenomena, leading to metallosis of surrounding tissues, corrosion of the parts [4] and inability to form a strong adhesion layer on the implant-bone interface. Implants consisting of "PEEK" plastics with osseoconductive and osseoinductive properties, and almost the same elasticity as that of human bones, are prone to biological resorption and may be subjected to wear with time. Moreover, wear products of polymers often lead to malignant transformations in neighboring tissues. From the point of biochemical compatibility with the body, bioactive ceramic materials are the most promising ones. However, significant limitation exists when using these materials, if the loads are considered. For example, brittleness of calcium hydroxyapatite (HAP) ceramics does not allow for making ceramic implant walls thinner than $5 \mathrm{~mm}$.

Provision of resistance to dynamic loads is an important prerequisite for locomotor system implants. During jumping and running motions of a patient, or during surgical procedures, the implant is affected to impact loads, which lead to microfracturing of the material, developing with further use and this can eventually result in implant destruction. It should be noted that physico-chemical properties of human tissues differ depending on sex, age, individual features, etc. [5], e.g., cortical tissue has elasticity modulus of $10 \mathrm{GPa}$, while for spongeous bone it is $450 \mathrm{MPa}$. Observed values of maximum equivalent stress do not exceed the strength limit which is $160 \mathrm{MPa}$ for a cortical bone [6], and 18$22 \mathrm{MPa}$ for a spongeous bone [7]. 
Considering the fact that widely used ceramic materials with low mechanical properties no longer comply with increasing requirements to strength and bone union duration [8], a pressing need in strengthened bioactive glass ceramics with controlled resorption terms has arised.

Due to a unique ability of uniting with a living bone and creating a strong biochemical bond with it, these materials are seen as the most effective among numerous non-organic materials used in bone implants and endoprosthetics for traumatology, maxillofacial surgery, dentistry and other fields of bone implantology. In future, bio glass ceramics and materials on their base may become a key in solving one of the most important problems of modern medicine - creating the artificial bone [9].

Significant disadvantage of bio glass ceramics is their low fracture resistance: critical stress intensity factor $\left(K_{l C}\right)$, a characteristics of this property, is lower than 1.12.0 MPa $\cdot \mathrm{m}^{1 / 2}$. However, both fracture resistance and mechanical strength of bio glass ceramics may be increased by employing certain approaches, namely:

- if vitreous production method is used, through directed crystal orientation, achieved by crystallization due to formation of a temperature gradient. Oblong calcium phosphate crystals formed in this process lead to the increase in bending strength of more than an order of magnitude (from 50 to $640 \mathrm{MPa}$ ) and a twofold increase in $K_{l C}$ (to up to $3.0-3.5 \mathrm{MPa} \cdot \mathrm{m}^{1 / 2}$ );

- if ceramic production method is used, through reinforcing glass ceramics with "whiskers" or filaments of $\mathrm{SiC}$, ceramic $\left(\mathrm{Al}_{2} \mathrm{O}_{3}, \mathrm{ZrO}_{2}\right)$ or metallic (titanium, steel) fine particles. In the former case, bending strength $\left(\sigma_{b}\right)$ increases up to $465 \mathrm{MPa}$ and $K_{l C}$ up to $4.2 \mathrm{MPa} \cdot \mathrm{m}^{1 / 2}$, i.e. fracture resistance is close to that of a bone $\left(6.0 \mathrm{MPa} \cdot \mathrm{m}^{1 / 2}\right)$. In the latter case, for example, with the ratio of glass ceramic and $\mathrm{ZrO}_{2}$ powders of $3: 2, \sigma_{b}$ reaches the values of 600-900 MPa.

That is why the creation of strengthened bioactive calcium phosphate-silicate sitalls for bone implants with controlled bone union, which are exploited under conditions of changing loads for bone tissue, is an actual scientific and practical task, for which this paper is directed.

The aim of the work is developing a strengthened calcium phosphate-silicate glass ceramics for bone tissue substitution in dynamically loaded areas.

\section{Experimental}

To achieve the aim specified the following problems have been set:

- analysis of accumulated experience in the field of creating bioactive glass ceramics and its strengthening;
- substantiating the choice of the base oxide system for obtaining glasses, investigating phase formation in it, and synthesis of model glasses;

- determining the influence of viscosity and phase composition on mechanical characteristics of developed glass ceramics;

- choosing technological parameters of thermal treatment of model glasses, required to obtain strengthened bioactive glass ceramics.

The obtained model glasses have been studied with physico-chemical investigation methods, which allowed to research the processes occurring in the glasses during thermal treatment. In particular, these methods were: differential thermal analysis (DTA), gradient-thermal and petrographic analyses. Viscosity of glasses has been studied with the thread elongation method on the viscosimeter by OJSC "Glass Institute" (Russian Federation). Values of mechanical properties have been measured with PMT-3, TMV-1000 hardness tester and elasticity modulus tester by a static method.

In order to obtain glass ceramics, powders of model glasses ground to the extent of residue on 063 sieve of less than $5 \%$ have been used. Specimens have been prepared by semi-dry pressing method. They have been given a shape of cylinders of $4 \mathrm{~mm}$ in diameter and $10 \mathrm{~mm}$ in height, using $2 \%$ carboxymethylcellulose solution as a temporary binder. Materials were treated for $30 \mathrm{~min}$ within the temperature range of $1023-1073 \mathrm{~K}$, depending on the composition. After thermal treatment, glass ceramics had insignificant porosity (less than $10 \%$ ), which is a consequence of sintering the narrow-fractioned glass powders with the size of the particles $\leq 60 \mu \mathrm{m}$. Labelling of glass ceramics corresponds to the model glasses they were obtained from.

\section{Results and Discussion}

\subsection{Development of Model Glasses}

Based on the cumulative experience of creating statically and dynamically loaded resorptive bioactive glass ceramics for maxillofacial surgery, BS-11 glass ceramics has been selected as a base for developing implant materials for endoprosthetics of longitudinal bones. BS-11 demonstrates osseointegration characteristics on the $90^{\text {th }}$ day and high density of osseoforming cells with the relative area of osseoforming tissue of 40.2 conditional units [10]. This is due to its high reactivity, with the degree of silicon-oxygen matrix binding $f_{S i}<0.32$ and content of crystalline phase of HAP roughly $55 \mathrm{vol} \%$. However, mechanical properties of developed composite material (BS-11Z) on the base of BS-11 glass ceramics and zirconia, at $\mathrm{ZrO}_{2}$ content of 5 
mass parts per 100 mass parts of glass ceramics, (Vickers hardness $H V=6200 \mathrm{MPa}$; microhardness $H=7350 \mathrm{MPa}$; fracture resistance index $K_{l C}=2.44 \mathrm{MPa} \cdot \mathrm{m}^{1 / 2}$; bending strength $\sigma_{b}=160 \mathrm{MPa}$ ) are not sufficient for the developed material to be used as endoprostethics of longitudinal bones of lower limbs.

High fracture resistance and optimal solubility, which are needed to form the apatite-like layer during a short time period, are the prerequisites of robust performance of an implant, which is made of bioactive glass ceramics, on dynamically loaded areas. Important condition for the strong bond on the implant-bone interface is accelerated formation of mineralized layer on the surface of an implant. This can be achieved by heterogeneous nucleation of apatite crystals [11], due to the presence of $\mathrm{Si}-\mathrm{OH}^{-}, \mathrm{Ti}-\mathrm{OH}^{-}, \mathrm{Zr}-\mathrm{OH}^{-}$structural elements on the surface of the material.

During the stage of collagen fibers synthesis and on the initial stages of bone biomineralization, silicon is associated with calcium, thus initiating the process of bone minerals deposition, it is also an important "transitional" element in the processes of generation and development of cartillage and bone structures. Simultaneous incorporation of $\mathrm{TiO}_{2}$ and $\mathrm{ZrO}_{2}$ into calcium phosphate-silicate glasses allows the intensification of HAP crystallization and decreases chemical resistance of the glass ceramics. Introduction of $\mathrm{ZrO}_{2}$ decreases the ability of glass ceramic material to form the layer of carbonate hydroxyapatite (CHAP) in the organism environment, but somewhat increases its microhardness and density and decreases TCLE. Also, simultaneous presence of $\mathrm{TiO}_{2}, \mathrm{ZrO}_{2}, \mathrm{MgO}, \mathrm{ZnO}$ significantly increases the strength of glasses and their chemical resistance against organic solvents. Introduction of magnesium and zinc oxides into the composition of glass ceramics allows to decrease the rate of HAP crystal growth, leading to formation of fine structure [12].

Formation of fine crystals with the size of approximately $0.1-1.0 \mu \mathrm{m}$, which are strongly interconnected with each other, and the presence of thin layers of glass make the strength of glass-ceramic material close to the theoretical one. This, along with complicated fracturing along crystal interfaces, is a prerequisite for high strength of bioactive materials, identical to that of solid metallic alloys. It allows to use the developed materials on dynamically loaded areas of a bone. Introduction of aluminium and boron oxides, which are localized in the tetrahedron, to the glass materials, creates conditions for formation of a continuous aluminiumphosphorous-oxygen framework, affecting the increase in chemical durability of the materials and decreasing their temperature coefficient of linear expansion (TCLE). Due to this, it is possible to create implants capable of withstanding sterilization and antiseptic treatment in the aggressive environments.
Considering the above points, the following requirements to the structure and properties of bioactive glass ceramics has been stipulated:

- fine volume-orientated crystallization of the model glass at one-stage thermal treatment method with the formation of strengthened bioactive structure;

- optimal solubility levels of glass ceramics in physiological environment for the short term (one month) formation of an apatite-like layer on the surface in vivo;

- leaching ions from the material to the solution in order to provide the apatite forming ability and biocide properties for bone formation and preventing inflammatory reactions upon the introduction of the implant into the body.

This will allow to obtain bioactive glass ceramics that belong to the class A group of biologically active substances, characterized by both osseoconduction (bone union on implant surface) and osseoinduction (activation and absorption of osseogeneous cells by the material, which stimulates growth of the bone on a material surface) [13].

Considering the above, a glass matrix has been developed based on $\mathrm{Na}_{2} \mathrm{O}-\mathrm{K}_{2} \mathrm{O}-\mathrm{Li}_{2} \mathrm{O}-\mathrm{ZnO}-\mathrm{CaO}-\mathrm{MgO}-$ $\mathrm{ZrO}_{2}-\mathrm{TiO}_{2}-\mathrm{CeO}_{2}-\mathrm{MnO}_{2}-\mathrm{Al}_{2} \mathrm{O}_{3}-\mathrm{B}_{2} \mathrm{O}_{3}-\mathrm{CaF}_{2}-\mathrm{P}_{2} \mathrm{O}_{5}-\mathrm{SiO}_{2}$ system. In this system, compositions of AS series glasses have been selected (wt \%): $\mathrm{SiO}_{2} 47.0-50.0 ; \mathrm{CaO} 15.0$ 17.0; $\mathrm{P}_{2} \mathrm{O}_{5}$ 9.0-10.0; $\mathrm{K}_{2} \mathrm{O} 4.0 ; \mathrm{Na}_{2} \mathrm{O} 3.5-6.0 ; \mathrm{Li}_{2} \mathrm{O} 2.0$ $4.0 ; \mathrm{Al}_{2} \mathrm{O}_{3}$ 2.0-3.0; $\mathrm{B}_{2} \mathrm{O}_{3} 4.0-5.0 ; \mathrm{ZnO} 1.0-3.0 ; \mathrm{ZrO}_{2} 0.5-$ 1.0; $\mathrm{TiO}_{2}$ 0.3-1.5; $\mathrm{MnO}_{2} 1.0-2.0 ; \mathrm{CaF}_{2}$ 0.5-2.4; $\mathrm{CeO}_{2}$ $0.4-0.5 ; \mathrm{MgO} 0.1-1.0$, as well as modifying additives $\Sigma$ $\left(\mathrm{Cu}_{2} \mathrm{O}, \mathrm{V}_{2} \mathrm{O}_{5}, \mathrm{MoO}_{3}, \mathrm{CoO}, \mathrm{SrO}, \mathrm{La}_{2} \mathrm{O}_{3}\right) 0.1$ with the ratio of $\mathrm{CaO} / \mathrm{P}_{2} \mathrm{O}_{5}=1.66-1.67$ to obtain materials in used conditions under dynamic loads (Table 1).

Experimental glasses of the AS series with labelling AS-1, AS-2, AS-3, AS-4, AS-5 were melted under identical conditions at $1523-1623 \mathrm{~K}$ in corundum crucibles followed by the cooling on a metal plate.

\subsection{Investigation of Mutual Effect of Viscosity and Crystallization Ability of Model Glasses Under Thermal Treatment}

Intensive crystallization is observed in the structure of model glasses after melting, which is determined by a significant amount of HAP crystalline phase of 20$30 \mathrm{wt} \%$. The highest amount of crystalline phase after melting is found in glasses AS-3 and AS-5, which, by their composition, belong to the low-silica area and have a high content of crystallization catalysts and phase forming components. Significant amount of crystalline phase for AS-3 and AS-5 glasses is due to a low structural viscosity compared to AS-1, AS-2 and AS-4 glasses. Considering the fact that fluctuation structure has a kinetic nature and so it develops the most in the systems with low energy 
barrier on the path of structural chemical transitions, with low relaxation times, crystallization of AS-3 and AS-5 on a nucleation stage is more intense. This results in a shift of the temperatures of intensive crystalline phase growth to a lower zone (913-923 K) when compared to AS-1, AS-2, AS-4 glasses of the high-silica area (953-973 K) (Fig. 1).

Table 1

Differences in the chemical compositions of the model glasses, their temperature-time mode of melting and treatment, characterization of main crystalline phases after ceramization

\begin{tabular}{|c|c|c|c|c|c|c|c|c|c|c|}
\hline \multirow{4}{*}{ Symbol } & \multicolumn{6}{|c|}{$\begin{array}{l}\text { Difference of model glasses by chemical composition, } \\
\text { wt \% }\end{array}$} & \multirow{4}{*}{$\begin{array}{c}\text { Melting } \\
\text { temperature, } \\
\mathrm{K}\end{array}$} & \multirow{4}{*}{$\begin{array}{c}\text { Thermal treatment } \\
\text { temperature }(T, \mathrm{~K}) / \\
\text { duration }(\tau, \mathrm{min})\end{array}$} & \multirow{2}{*}{\multicolumn{2}{|c|}{ HAP amount, vol \% }} \\
\hline & \multirow{2}{*}{\multicolumn{3}{|c|}{$\begin{array}{l}\text { Phase forming } \\
\text { components }\end{array}$}} & \multirow{2}{*}{\multicolumn{3}{|c|}{ Crystallization catalysts }} & & & & \\
\hline & & & & & & & & & After & After thermal \\
\hline & $\mathrm{CaO}$ & $\mathrm{P}_{2} \mathrm{O}_{5}$ & $\mathrm{SiO}_{2}$ & $\mathrm{ZnO}$ & $\Sigma\left(\mathrm{TiO}_{2}, \mathrm{ZrO}_{2}, \mathrm{CeO}_{2}\right)$ & $\mathrm{CaF}_{2}$ & & & melting & treatme \\
\hline AS-1 & 15.0 & 9.0 & 50.0 & 3.0 & 1.4 & 0.5 & 1523 & $1073 / 15$ & 20 & 50 \\
\hline $\mathrm{AS}-2$ & 15.0 & 9.0 & 50.0 & 1.0 & 2.4 & 0.5 & 1553 & $1073 / 15$ & 20 & 60 \\
\hline AS-3 & 17.0 & 10.0 & 47.0 & 3.0 & 1.3 & 1.0 & 1533 & $1023 / 15$ & 30 & 60 \\
\hline $\mathrm{AS}-4$ & 15.0 & 9.0 & 50.0 & 3.0 & 2.0 & 1.0 & 1623 & $1073 / 15$ & 20 & 50 \\
\hline AS-5 & 17.0 & 10.0 & 47.0 & 2.5 & 2.4 & 2.4 & 1523 & $1023 / 15$ & 25 & 60 \\
\hline
\end{tabular}

Steep and highly distinct peaks of exotermic effects on the thermograms of AS-3 and AS-5 glasses at 913 and $923 \mathrm{~K}$ are the evidence of the fineness of the crystalline structure formed. However, upon the temperature increasing to $973 \mathrm{~K}$, for the glass AS-3, the area of endothermic effect widens, and with the further temperature increase the thermogram curve flattens, which can be the evidence of crystal phase growing in size. For AS-5 glass, the peak of small exothermic effect is observed near $973 \mathrm{~K}$, which might be due to a residual buildup of HAP crystals with their subsequent increase in volume, starting from 1013 to $1123 \mathrm{~K}$. Flattened pattern of thermograms of AS-1, AS-2, AS-4 glasses in the temperature range of 813-973 K allows to conclude that there is an increase in a crystalline phase size in this temperature range. Decrease in height of the exothermic effects at 973 and $953 \mathrm{~K}$ for the glasses AS- 1 and AS-4 is the evidence of decrease in their crystallization ability compared to other experimental glasses. Upon the further temperature increase to above $973 \mathrm{~K}$, steep peaks of exothermic effects are observed for the experimental glasses, which are an indication of the increase in crystalline phase content to $60-70 \mathrm{vol} \%$ and its fine structure. The only exception is AS-4 glass, which has a flat peak and low endothermic effect area located before exothermic effect, which is a result of crystal growth.

Characteristics of the crystalline phase observed during thermal treatment of the experimental glasses have been analyzed using gradient thermal and petrographic analysis methods. In the temperature range of 913-923 K, the content of crystalline phase is $35-40$ vol \% for AS-2, AS-3 and AS- 5 glasses, whereas for AS- 1 and AS-4 it is only $30 \mathrm{vol} \%$ (Fig. 2). During thermal treatment of experimental glasses in the temperature range of $1023-1073 \mathrm{~K}$, the crystalline phase content reaches
50-60 vol \%, which is the evidence of volume crystallization. However, the formation of fine structure during thermal treatment, with the crystalline phase content of approximately $70 \mathrm{vol} \%$, being a critical factor of material strength, is only observed for AS-3 and AS-5 glasses. Emergence of vitreous phase and final healing of fractures for AS-1, AS-2 and AS-4 glasses occurs at approximately $1073 \mathrm{~K}$, and at approximately $1023 \mathrm{~K}$ for the glasses AS-3 and AS-5. The increase of the temperature to $1123 \mathrm{~K}$ for AS-4 glass leads to crystals enlargement to over $1 \mu \mathrm{m}$, which will affect its structure positioning.

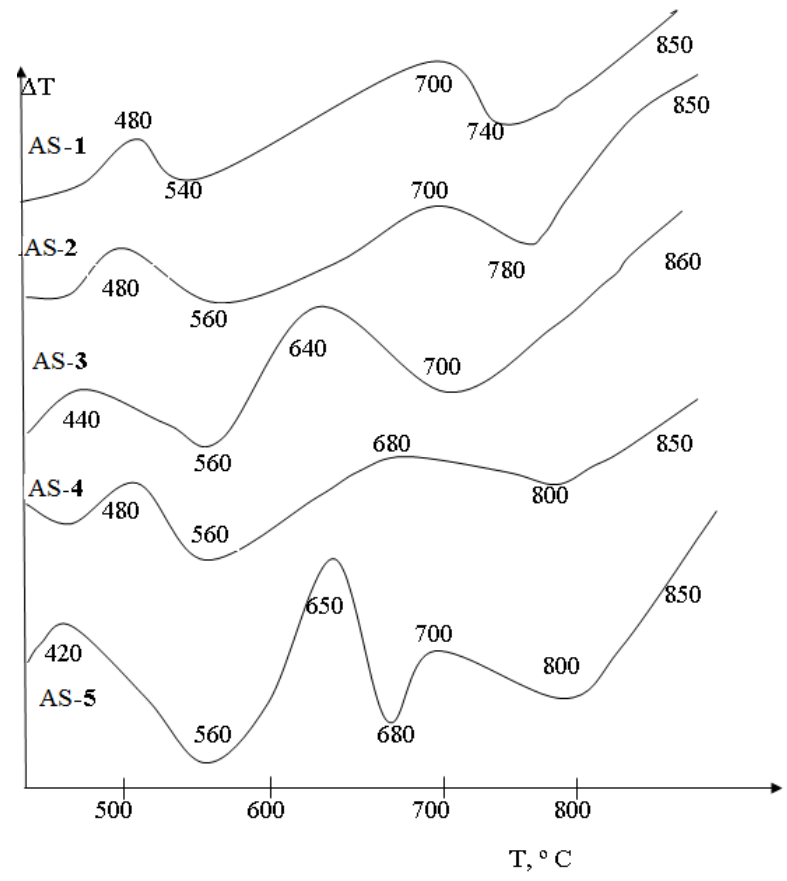

Fig. 1. Thermal effects in the model glasses 
Formation of highly viscous framework during the melting of AS-3 and AS-5, due to the high content of crystalline phase after melting, creates conditions for shortterm phase separation, which allows the formation of crystallized structure with a high content of crystalline phase upon cooling of the melt. The important role of phase separation is the fact that conditions for slowing down the crystal growth are created during thermal treatment. It is an important concept in a creating strengthened glass-ceramic structure in model glasses during thermal treatment.

Based on the analysis of viscosity (Fig. 3) it has been established that all model glasses have the abnormal increase of crystallization ability in the glass interval $T_{g^{-}}$ $T_{f}$, which is due to a maximum of fluctuations formation at $823 \mathrm{~K}$. However, viscosity value and its characteristics in this temperature range are quite different for experimental glasses. Thus, the increase of crystallization viscosity for AS-5, similarly to its thermogram (Fig. 1), is more intensive, which can be an evidence of significant amount of crystal nuclei formed in the lower temperature range. This is very important for strengthened glassceramic structure formation during thermal treatment. It is during low-temperature crystallization that glass "selects" metastable crystalline phases that are the easiest for the glass to wet, and which, as a result, are most bound to the glass. Due to this, their re-crystallizing into stable phases in a glass structure at elevated temperatures will not result in decrease of the strength characteristics.

Insignificant increase in viscosity for AS-1 and AS-4 glasses to $\eta=10^{9.55} \mathrm{~Pa} \cdot \mathrm{s}$ at $823 \mathrm{~K}$ is the evidence of not only intensive nucleation, but also of the growth of crystals formed during cooling, after glass material melting, which can adversely affect the strength charac- teristics of the material. For the experimental glasses, the curve of temperature dependence is considered optimal when its maximum is shifted towards the temperatures below softening point, i.e. towards the viscosity values of $\eta \approx 10^{9.36} \mathrm{~Pa} \cdot \mathrm{s}[14]$.

Considering specific features of the crystallization process of experimental glasses, a single stage mode of thermal treatment (1023-1073 K) in a short time interval ( $\tau \approx 15 \mathrm{~min}$ ) has been selected. After thermal treatment, experimental glass-ceramic materials of AS series contained crystalline HAP in the amount of 50-60 vol \%. Based on the possibility of achieving fine crystalline structure with HAP content of $60 \mathrm{vol} \%$ during lowtemperature thermal treatment, AS-5 glass ceramics has been selected for further investigations.

\subsection{Synthesis of Composite Materials and Investigation of their Mechanical Properties}

Investigation of mechanical properties of AS-1, AS-4 and AS-5 glass ceramics, allowed to establish that the highest values of hardness $(H V)$ are observed for AS-1 and AS-4 specimens, because of comparatively high content of zinc, magnesium and lanthanum oxides in their composition (Table 2). As for AS-5 specimen, its hardness is somewhat lower and approximates that of bone tissue. However, the experimental materials have insufficient fracture resistance to be used as a base for dynamically loaded implants (Table 2, Fig. 4a). Elasticity modulus $(E)$ of experimental materials is determined by the packing density and is the highest for AS-5, the one with the highest content of crystalline phase.

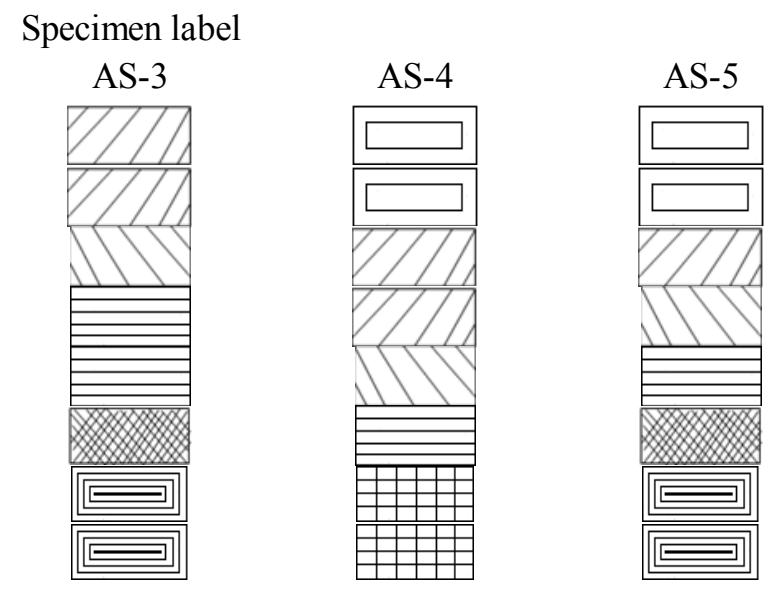

Temperature, $\mathrm{K}$

After melting

823

873

923

973

1023

1073

1123
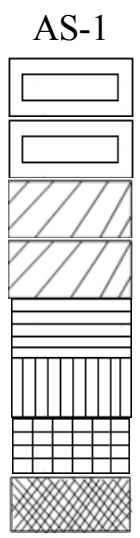

AS-2

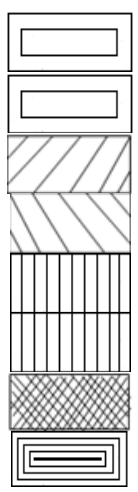

- volume crystallization $20-25 \mathrm{vol} \%, \nabla / 7$ - volume crystallization $30 \mathrm{vol} \%, 1 / \mathrm{V}$ - volume crystallization $35 \mathrm{vol} \%$,

- volume crystallization $40 \mathrm{vol} \%$, 而而乔 - volume crystallization 45 vol \%, - volume crystallization $60 \mathrm{vol} \%$, 怔 - volume crystallization $70 \mathrm{vol} \%$

Fig. 2. Phase transitions in the model glasses during thermal treatment 


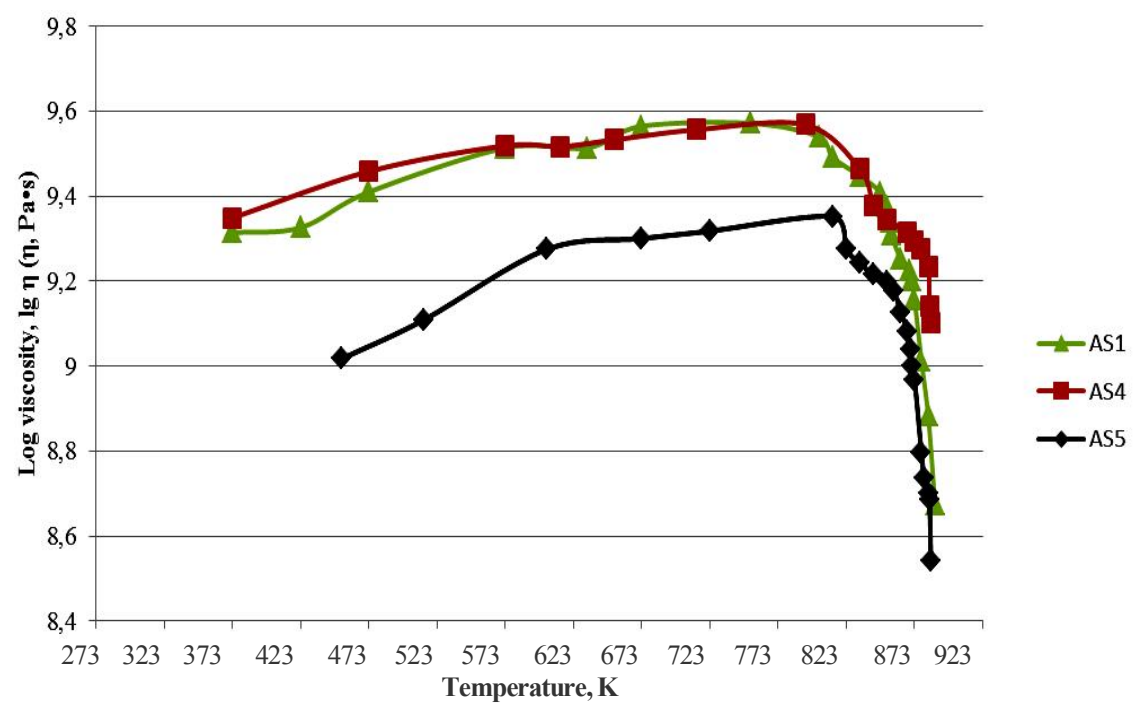

Fig. 3. Viscosity $v s$. temperature curve of model glasses

Table 2

Mechanical properties and density of experimental materials

\begin{tabular}{|c|c|c|c|c|c|}
\hline \multirow{2}{*}{ Material } & \multirow{2}{*}{ Density, $\mathrm{g} / \mathrm{cm}^{3}$} & \multicolumn{4}{|c|}{ Mechanical properties } \\
\cline { 3 - 5 } & 2.20 & $K_{I C}, \mathrm{MPa} \cdot \mathrm{m}^{\mathrm{I} / 2}$ & $H V, \mathrm{MPa}$ & $\sigma_{b}, \mathrm{MPa}$ & $E, \mathrm{MPa}$ \\
\hline AS-1 & 2.20 & 1.20 & 4870 & 100 & 90 \\
\hline AS-4 & 2.20 & 2.00 & 4650 & 100 & 85 \\
\hline AS-5 & 2.30 & 2.80 & 3530 & 110 & 100 \\
\hline ASZ 5-10 & 2.35 & 1.67 & 3800 & 160 & - \\
\hline ASZ 5-20 & 2.35 & 2.44 & 6200 & 100 & - \\
\hline BS-11Z & $1.20-3.99[15]$ & 6.00 & $226-3071[15]$ & $88.8-955.2[15]$ & - \\
\hline Bone tissue & \multicolumn{3}{|c|}{} & &
\end{tabular}

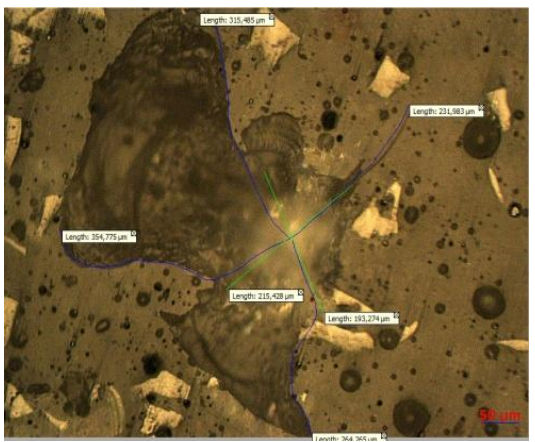

a)

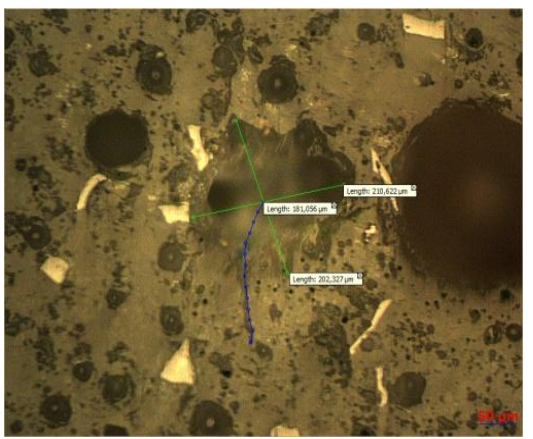

b)

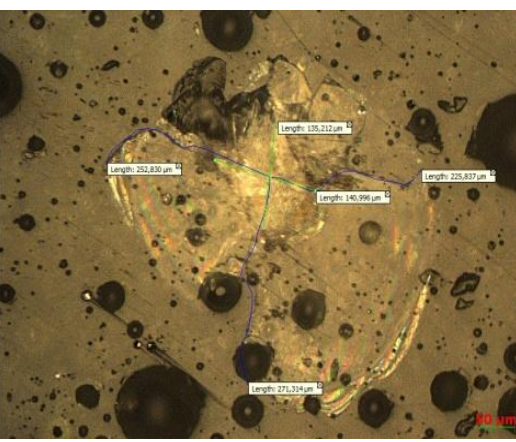

c)

Fig. 4. Structure microphotographs of experimental materials after indentation loading with $5000 \mathrm{~g}$ Vickers diamond pyramid: ASZ -5 (a); ASZ 5-10 (b) and ASZ 5-20 (c)

The increase in fracture resistance for AS-5 material has been attained by introducing yttrium oxidestabilozed zirconium dioxide. Transformation strengthening of the glass matrix by controllable transition of tetragonal $\mathrm{ZrO}_{2}$ to the monoclinic phase is accompanied by volume increase of $3 \mathrm{vol} \%$. Due to the microcracking of the glass matrix, its strength increases by deflection and bifurcation of developed cracks [13].
Composite materials of ASZ series were obtained based on AS-5 glass ceramics and zirconium dioxide in the amount of 10 and 20 mass parts per 100 mass parts of glass material, labelled ASZ 5-10 and ASZ 5-20, respectively.

Mechanical properties of developed composite materials ASZ are increasing at large, although with different intensity (Figs. 4b and 4c). The highest fracture 
viscosity $\left(K_{l C}\right)$ yield and minor increase in hardness are observed for the composite material ASZ 5-10, which is connected with structural characteristics of this material, namely due to blocking of microfractures and their furcation by pores, fine crystalline phase and fillers.

The values of density and mechanical properties of ASZ 5-10 composite material being close to those of bone tissue allow to avoid the loads on bone tissue when implants on the base of this material are functioning within a living organism.

\section{Conclusions}

Analysis of cumulative experience in the field of creating bioactive glass ceramics and methods of their strengthening allowed to establish the perspectiveness of using strengthened calcium phosphate-silicate glasses in implants for substitution of bone tissue subjected to dynamic loads. Choice of basic $\mathrm{Na}_{2} \mathrm{O}-\mathrm{K}_{2} \mathrm{O}-\mathrm{Li}_{2} \mathrm{O}-\mathrm{ZnO}-$ $\mathrm{CaO}-\mathrm{MgO}-\mathrm{ZrO}_{2}-\mathrm{TiO}_{2}-\mathrm{CeO}_{2}-\mathrm{MnO}_{2}-\mathrm{Al}_{2} \mathrm{O}_{3}-\mathrm{B}_{2} \mathrm{O}_{3}-$ $\mathrm{CaF}_{2}-\mathrm{P}_{2} \mathrm{O}_{5}-\mathrm{SiO}_{2}$ system for obtaining glass ceramics has been substantiated, and model glasses with the ratio of $\mathrm{CaO} / \mathrm{P}_{2} \mathrm{O}_{5}=1.66-1.67$ have been obtained.

Phase formation mechanism has been investigated. It was established that nucleation at viscosity values of $\eta \approx$ $10^{9.36} \mathrm{~Pa} \cdot \mathrm{s}(823 \mathrm{~K})$ and intensive crystallization (at 913$923 \mathrm{~K}$ ) allows to provide the formation of glass-ceramic structure with hydroxyapatite content of $60 \mathrm{vol} \%$, in conditions of single-stage low-temperature short-term (15 min) thermal treatment regime (1023-1073 K).

It has been found that introduction of yttrium-oxide stabilized zirconium dioxide into the composition of developed calcium phosphate-silicate glasses in the amount of 10 mass parts allows to achieve the following mechanical properties: $K_{l C}=2.8 \mathrm{MPa} \cdot \mathrm{m}^{1 / 2}$, $H V=3800 \mathrm{MPa}, \sigma_{b}=160 \mathrm{MPa}$, which are close to that of bone tissue. Obtained results can be recommended for designing biocompatible bone implants for implants of locomotor system.

\section{References}

[1] Navarro M., Michiardi A., Castaño O., Planell J.A.: J. R. Soc. Interface, 2008, 5, 0151. https://doi.org/10.1098/rsif.2008.0151
[2] Kirilova I., Sadovoy M., Podorozhnaya V. et al.: Hirurgiya Pozvonochnika, 2013, 4, 52. https://doi.org/10.14531/ss2013.4.52-62

[3] El-Ghannam A.: Expert Rev. Med. Devices, 2005, $2,87$. https://doi.org/10.1586/17434440.2.1.87

[4] Tatarinov V..: Pat. RU 2382619, Publ. Oct. 27, 2010.

[5] Veretelnik O.: Vestnik NTU "HPI". Tem. Vyip.:

Mashinovedenie i SAPR, 2008, 2, 14.

[6] Boyko I., Sabsay A., Makarov V., Radzhabo O.: Visnik Sev. NTU, 2012, 133, 355.

[7] Kukin I., Kirpichyov I., Maslov L., Vihrev S.: Fundam. Res., 2013, 7, 328.

[8] Kokubo T.: Biomaterials, 1991, 12, 155.

https://doi.org/10.1016/0142-9612(91)90194-F

[9] Sarkisov P., Mikhailenko N., Khavala V.: Glass Ceram., 1994, 50, 372. https://doi.org/10.1007/BF00683581

[10] Savvova O., Bragina L., Shadrina G. et al.: Glass Ceram., 2017, 74, 29. https://doi.org/10.1007/s10717-017-9922-3

[11] Patel N., Best S., Bonfield W. et al.: J. Mater. Sci. Mater. Med., 2002, 13, 1199. https://doi.org/10.1023/A:1021114710076

[12] Savvova O., Babich O., Fesenko O. et al.: Biocompatible GlassCeramic Coatings. Calcium-Phosphate-Silicate Coatings on Titanium for Dental Implants, SIA OmniScriptum Publishing, Riga 2018.

[13] Gerhardt L.-C., Boccaccini A.: Materials, 2010, 3, 3867.

https://doi.org/10.3390/ma3073867

[14] Chuyko A., Kalinovskaya D., Pogranichnaya K.: Ortopediya,

Travmatologiya i Protezirovanie, $2011,3,29$.

[15] Savvova O., Babich O., Shadrina G.: Funct. Mater., 2014, 21,

421. https://doi.org/10.15407/fm21.04.421

Received: April 02, 2018 / Revised: April 25, 2018 / Accepted: September 14, 2018

\section{РОЗРОБЛЕННЯ ЗМЩНЕНИХ БІОАКТИВНИХ КАЛЬЦІЙФОСФАТОСИЛІКАТНИХ СИТАЛІВ ДЛЯ КІСТКОВИХ ІМПЛАНТАТІВ}

\begin{abstract}
Анотація. Проаналізовано накопичений досвід у напрямку створення біоактивних ситалів для кісткових імплантатів та методів їх зміџнення. Обрано склади та синтезовано модельні стекла, досліджено взаємозв'язок кристалізаційної здатності та в'язкості ситалів. Синтезовано композииійні матеріали на основі ситалів $i$ діоксиду иирконію, досліджено їх механічні властивості та встановлено перспективність їх використання при створенні кісткових імплантатів.
\end{abstract}

Ключові слова: кальиійфосфатосилікатні ситали, кристалізаиійна здатність, в'язкість, механічні властивості, зміцнення, кісткове ендопротезування. 